\begin{tabular}{|l|l|l|}
\hline \multicolumn{2}{|c|}{ PublisherInfo } \\
\hline \hline PublisherName & $:$ & BioMed Central \\
\hline \hline PublisherLocation & $:$ & London \\
\hline \hline PublisherImprintName & $:$ & BioMed Central \\
\hline \hline
\end{tabular}

\title{
Kinase mutations in cancer
}

\begin{tabular}{|l|c|l||}
\hline \multicolumn{2}{|c|}{ ArticleInfo } \\
\hline \hline ArticleID & $:$ & 4500 \\
\hline \hline ArticleDOI & $:$ & $10.1186 /$ gb-spotlight-20020611-01 \\
\hline \hline ArticleCitationID & $:$ & spotlight-20020611-01 \\
\hline \hline ArticleSequenceNumber & $:$ & 166 \\
\hline \hline ArticleCategory & $:$ & Research news \\
\hline ArticleFirstPage & $:$ & 1 \\
\hline \hline ArticleLastPage & $:$ & 2 \\
\hline \hline & & RegistrationDate : 2002-6-11 \\
\hline ArticleHistory & $:$ & OnlineDate \\
\hline \hline ArticleCopyright & $:$ & BioMed Central Ltd2002-6-11 \\
\hline \hline ArticleGrants & $:$ & \\
\hline \hline ArticleContext & $:$ & 130593311 \\
\hline \hline
\end{tabular}




\section{Jonathan B Weitzman}

Email: jonathanweitzman@hotmail.com

The RAS-RAF pathway regulates mitogenic signal transduction, and oncogenic $R A S$ mutations are found in 15\% of human cancers. In an Advanced Online Publication in Nature, Davies et al. describe results of a systematic genome-wide screen for mutations of genes in this pathway (9 June 2001, DOI:10.1038/nature00766). They found examples of somatic substitution mutations in the human BRAF gene in cancer cells. Analysis of over 500 cancer cell lines revealed a high mutation frequency in malignant melanomas, as well as mutations in a wide range of other tumor types. Mutant forms of the BRAF protein had elevated kinase activity, resulting in signalling and increased transforming capacity. Furthermore, Davies et al. found cancer cell lines that contain oncogenic mutations in both the $R A S$ and $B R A F$ genes, suggesting that tandem-activating mutations in more than one component of a signalling pathway may contribute to tumorigenesis.

\section{References}

1. Control of the ERK MAP kinase cascade by Ras and Raf

2. Nature, [http://www.nature.com]

This PDF file was created after publication. 